\title{
Do arquivo ao repertório: passagens pela poesia de Luiz Bacellar
}

Resumo: Esta pesquisa dedica-se a Frauta de barro (1963), de Luiz Bacellar. Acredita-se que o poeta brasileiro problematize os limites do arquivo ao pôr na ordem do dia materiais culturais que escapam às formas tradicionais de arquivamento. Para avaliar esse problema e as operações internas aos poemas, serão consideradas as noções de arquivo e repertório, segundo a perspectiva de Diana Taylor (2013). Ao fim, busca-se evidenciar como a poesia repõe essas dimensões, esboroando limites e desfazendo compreensões cristalizadas.

Palavras-chave: Poesia brasileira do século XX, Luiz Bacellar, arquivo

Abstract: This research revolves around Frauta de barro (1963), by Luiz Bacellar. It is believed that the Brazilian poet problematizes the limits of "archives" when he works with cultural materials that escape the traditional archiving forms. In order to analyze this issue and the operations within the poems, this paper will take into consideration the notions of archive and repertoire - in consonance with Diana Taylor's (2013) perspective. In the end, the aim is to bring light to the ways in which the poetry shows its dimensions, erasing limits and disassembling ingrained ideas.

Keywords: 20th century Brazilian poetry, Luiz Bacellar, archives

Fazer um trajeto por nomes, títulos e estéticas comumente leva a crítica ao rastreio do que foi "arquivado" em uma obra. Assim se investigam anotações, edições, autores eleitos e técnicas emuladas. Reinaldo Marques compreende que os elementos que compõem o arquivo literário estão a serviço da comunidade imaginada. Por esse motivo, adverte: o pesquisador deve agir como um anarquivista, uma vez "[...] no arquivo da cultura letrada, a par do cunho libidinal, suas peças restam como fragmentos de outra lógica 
simbólica e cultural, indiciando a persistência da voz no mundo da letra [...]" (Marques 2015: 123). Nesse sentido, o conteúdo do que foi arquivado pode apontar para outra direção:

[...] os elementos descartados, as memórias dos grupos subalternos, das minorias, que foram alijados do processo de enunciação do relato legitimador da nação, costumam se insinuar pelo vazio e pelo fragmento, como resíduo inclassificável, no arquivo das memórias oficiais da comunidade nacional. De tal maneira que o tempo pedagógico é atravessado e rasurado por outros relatos e temporalidades, de cunho contestador e transgressor da unidade nacional, evidenciando-se a heterogeneidade da nação moderna, seu hibridismo cultural. (Marques 2015: 154)

Por esse prisma, compreende-se que autores também lançam luzes para o que muitas vezes está fora da taxonomia do arquivo. Quando se dedicam a espaços locais, uma nova gama de questões se torna possível, desde que afastadas de polarizações nas quais o local é considerado inferior e antinômico do nacional ou do cosmopolita. Esse é o contexto em que está inserido o livro de Luiz Bacellar. Em Frauta de barro (1963), o poeta apresenta uma paisagem urbana filtrada pela memória. Sobre ela se deseja fazer uma cartografia, rastreando não os lugares pelos quais o poeta circula, mas a dinâmica entre sujeito poético e paisagem, a qual engendra uma máscara própria. A performance do poeta lança mão da figura literária do chiffonnier, para, em seguida, mostrar o argumento da incorporação de coisas que escapam ao gesto hegemônico de arquivamento.

Embora o ambiente se transforme de um poema a outro em "Variações sobre um prólogo", primeiro poema do livro, eles guardam entre si a ação de colecionador de coisas. Da amorfa e irregular melodia à organização; da virtualidade da memória da primeira parte à concretude duas últimas, os sentidos de "colheita" e "coleta" tornam-se indissociáveis quando os alvos dessas ações são o "mato" e o "monturo" (duas formas de remissão à memória no poema). Não há neles uma propalação de situações grandiosas nem um embelezamento do material com que faz poesia. Em vez de símbolos que designam nobreza, tem-se a germinação de plantas baixas e os restos do lixo. O leitor está diante de um sujeito poético que garimpa conscientemente pedaços de um mundo provinciano (sugerido pelas indagações do poema a seguir); logo, esse mesmo mundo é o início e o limite de seu canto.

Nos longes da infância paro;

há uma inscrição sobre o muro;

Frauta clara, arroio escuro,

frauta escura, arroio claro.

E esse cavalo capenga? 


\begin{abstract}
E esse espelho espedaçado?
E a cabra? E o velho soldado?

E essa casa solarenga?

Tudo volta do monturo

da memória em rebuliço.

Mas tudo volta tão puro!...

$E$, mais puro que tudo isso,

essa anárquica inscrição

feita no muro a carvão.
\end{abstract}

São temas recomeçados

na minha vária canção.

(Bacellar 2011: 23)

O poema é aberto por um dos recortes do passado, cuja espacialização o converte em habitação. E nela o poeta pode momentaneamente parar. O plural confere imprecisão aos loci e garante ao pretérito a nebulosidade que dramatiza o acesso à lembrança e ratifica a distância entre os tempos. Há um contraste entre a rigidez do "muro", suporte onde é inscrita a palavra, e o "arroio", alusão à fluidez no par imagético água-lembrança. A concretude é extrapolada pelo símbolo aquático, sobrepondo a memória ao registro. Isso significa que o suporte é limitado, porque incapaz de apreender tudo o que advém das lembranças. Em contrapartida, melodia e natureza embaralham-se no quiasmo, pondo em primeiro plano instrumento e paisagem e compondo um efeito visual para a memória. Esse recurso indica na imprecisão do que se vê a impossibilidade de a memória ser totalizante. E é com esse efeito que uma segunda transformação acontece: os termos "frauta" e "arroio", antes individuais, tornam-se indissociáveis, em nova alusão à criação a partir do barro.

A enumeração na segunda estrofe do poema segue o impulso da imagem do "arroio" e jorra caoticamente novos termos, abrindo ramificações com os temas que serão reencontrados posteriormente no livro. Eles são lançados em forma de indagações, as quais expõem os alvos (as dimensões) cantadas pelo poeta. A aparência de desordem na apresentação das imagens contrasta com a regularidade do verso, o que reforça o mecanismo da memória sobre um constructo informe, que vai sendo modulado paulatinamente. Na terceira estrofe, recolhem-se os sentidos dos vocábulos anteriores. Nesse momento, é indicada a origem do "Tudo" que retorna. A expressão "monturo da memória” traz o ponto de partida que coincide com os gestos de segregação e reunião, atitudes que ele retoma diante do lixo como matéria para escrever o poema. 
Luiz Bacellar dialoga com um tema conhecido na história literária: o chiffonnier. Essa é uma figura conhecida na cultura francesa do século XIX, quando o papel era feito com trapos (chiffons), fazendo do chiffonnier um agente importante para Paris, na medida em que coletava o lixo e movia parte da economia..$^{1}$ Ele abarcava três funções, as quais mesclavam setores diferentes de Paris: agente da modernização da sociedade, impacto sobre economia e mobilização da cultura. Porém, a partir do momento em que a celulose suplanta o papel de trapos, a logística da coleta de lixo passa a ser organizada de maneira diferente, o que leva o chiffonnier para o lugar distante de um tipo parisiense, a ser cristalizado em representações artísticas. ${ }^{2}$

Dos vários exemplos de Antoine Compagnon, destaca-se o livro de Les Hermites en Liberté, de Etienne de Jouy, em que há uma crônica datada de 1824, sob o título "Le chiffonnier littérateur". 3 Ao final do texto, há uma figura com duas personagens em direção ao muro à direita da imagem; no centro, levemente à esquerda está o escritor, observando os papéis velhos no cesto sobre as costas do chiffonnier. O segundo personagem, curvado e mais à direita, executa seu trabalho. Cada um deles porta os objetos que lhes representam, respectivamente o livro e o crochet. Quando as gramáticas visual e textual coadunam seus significados em função dos trapos, recoloca-se em cena o valor da arte, sua origem e seu destino. Não se trata de elevação ou rebaixamento de uma ou outra figura, isto é, do preconceito sobre o que seria alto ou baixo em seus ofícios, mas de perceber que ideias de criação e de destruição não são necessariamente opositoras, apesar de suas diferenças. Há proximidade entre os símbolos do texto e da imagem, o que chama a atenção ao chiffonnier como um compilador que se torna uma espécie de coletor. Por fim, a justaposição dos termos "chiffonnier" e "compilateur" na referida crônica sugere metaforicamente que a literatura também nascerá do processo com o não convencional.

Depreende-se desse chiffonnier a metáfora daquele que se detém sobre o lixo tal qual um compilador sobre um arquivo. Distinguir, combinar, separar, comparar, apurar, todas são atitudes de um escritor; e "compilar" é uma etapa de um trabalho com a memória. Observando essa ação no poema de Frauta de barro, nota-se que, embora não sejam grandiosos, os casos tematizados ganham destaque. A proximidade do ato de compilar a memória aponta para o mundo desordenado. Esse, entretanto, é o espaço necessário para a criatividade. No poema, é pela identidade entre lixo e memória que essa compilação se torna significativa. Ambos são contíguos à inscrição "anárquica" no muro. Na anarquia dessa inscrição reside um modo da enunciação poética. Ela serve ao poeta como reflexo de sua palavra. No atual caso, a viagem que o poeta traçará pelas memórias será um "percurso anárquico", porque, apesar de avançar no plano geográfico da cidade, ele estará, simultaneamente, retrocedendo no tempo à revelia da força do presente.

Como outros poetas que escreveram sobre temas tradicionais, Luiz Bacellar busca dar sustentação às suas próprias práticas. Seu argumento lança mão de duas ideias. Ele se afasta da concepção de alta poesia, ao mesmo tempo que reinventa a figura do chiffonnier para convertê-la em um cantor popular. O traço melancólico é modificado pelo 
"tom faceiro e gaiato" (Bacellar 2011: 22) mais forte nos versos finais. Nesse sentido, o refrão é sintomático. Como um strambotto, ele é

um cantarzinho de conteúdo lírico, galhofeiro ou sentencioso, de que, por um processo de reelaboração mais ou menos culto, mais ou menos popular, se tiraram em diversos tempos e lugares, as carjas mozárabes, as cantigas paralelísticas galego-portuguesas e os strambotti italianos. (Lapa 1970: 90)

Ele contém o núcleo da ação performática de Frauta de barro. A alteração verbal (de "É o tema recomeçado" para "São os temas recomeçados") dinamiza o que seria cristalizado, modificando significativamente a "vária canção". Esse traço de repetição com diferença demonstra o gesto de recomeço incessante afeito à tradição popular, o qual transcende espaços e tempos e se atualiza a cada canto. Desse modo se esclarece a transformação do próprio canto sem nunca se reproduzir de forma idêntica.

Outra perspectiva deve, então, ser considerada. Se, de um ponto de vista histórico-literário, Luiz Bacellar demonstra conhecimento da tradição medieval, à qual conjuga outros temas e autores, o refrão também põe em jogo outro paradigma. "Tradição" não se restringe à memória literária e ocidental. A palavra igualmente se refere a outras vozes existentes na cultura popular. Fazer com que essa polissemia repouse sobre essa poesia revela que a performance em Frauta de barro não é mero recurso criativo no uso da língua ou jogo verbal bem-sucedido. É "um processo, uma práxis, uma episteme, um modo de transmissão, uma realização e um modo de intervir no mundo" (Taylor 2013: 44). A obra transmite um aparato cultural que vai do paradigma do registro ao que a ele escapa, isto é, do arquivável ao anarquivável. O rastreio de fontes de leitura de Luiz Bacellar aponta para o caráter duradouro de um arquivo construído com o estudo de autores dispostos em uma historiografia literária (a exemplo da figura do chiffonnier e de autores como François Villon, Casimiro de Abreu e Manuel Bandeira). Essa é apenas possível pela escrita, a qual garante a difusão de autores e obras, independentemente da distância geográfica entre eles. Ao mesmo tempo, porém, estão presentes conhecimentos incorporados (Taylor 2013).

Sobre essa dupla atuação, Luana Aguiar Moreira e Allison Leão escrevem:

[...] a poética de Bacellar vai se estabelecendo por meio de certas chaves a princípio exteriores à sua poesia, como a música (tout court), as influências artísticas e a tradição literária que Ihe serviram de fonte criadora, ao mesmo tempo em que internaliza traços dessas matrizes transfigurando-os num ethos próprio e numa performance estética que teria como um de seus efeitos a própria repetição; em outras palavras, canibalizando aspectos de tais matrizes, assimilando-os a um ser na verdade gestado por elas, a poesia de Bacellar não poderia ter outra forma de expressão que não fosse o provisório, dado o espectro múltiplo e transitório que circunda as bases de sua criação. Assim, a materialidade da obra está submetida a uma 
energia difusa que a antecede e promove uma força ininterrupta que a sucede, como as reedições nos fazem crer. (Moreira/Leão 2020: 209)

O caminho detectado pelos críticos diz respeito ao estudo das transformações entre as sete edições de Frauta de barro. No entanto, acredita-se que essa operação canibalizadora estaria concentrada em uma etapa anterior, já no poema "Variações sobre um prólogo", o qual pode ser tomado como estrutura de pensamento. Ele prevê o recomeço e a variação, ambos termos-chave desse vocabulário poético. O provisório é a marca da finitude; corresponde a uma estimativa de um tempo que se pode ter momentaneamente à mão. No poema, o recomeço declara não só a consciência do sujeito poético sobre essa marca, mas informa a matriz propulsora dessa poesia. Sua potência está na possibilidade de modificação por meio da inserção de algo novo. A variação, nesse caso, faz o deslocamento e promove a diferenciação. Essas ações simultâneas indicam os fundamentos da performance das máscaras poéticas. Trata-se de permuta constante, em que pese o valor da continuidade da transformação. O poeta apela para uma ação que dê consistência e coerência para o prólogo e, por extensão, para a obra. Repetir continuamente indica uma dinâmica contra o tempo. A efemeridade de suas ações demanda novas projeções, as quais denunciam a prossecução temporal irrefreável. Uma nova máscara sucede à anterior, de modo que da precedente reste apenas uma sombra. O que fica é o desejo sempre presente movendo esse duelo entre memória e esquecimento.

A poesia de Luiz Bacellar levanta um questionamento acerca do que, fora de um tempo estipulado, não é mais alvo de interesse do mundo industrial. A exemplo de "10 sonetos de bolso", o poeta compõe sua poesia a partir do reconhecimento de um descompasso. Do ponto de vista do progresso, a materialidade dos objetos denuncia o envelhecimento e os traços históricos de uma época. Esse é o caso de "Soneto do porta-níqueis", em que o poeta apresenta a mudança da moeda brasileira de cruzados para cruzeiros (Bacellar 2013: 32). Nos poemas sobre o espaço da cidade, a marca do tempo é exposta pela arquitetura arruinada. Frauta de barro insere a durabilidade provisória como um problema a ser pensado poeticamente. Quando ela se esgota, ocorrem o descarte de certos materiais arquiváveis e o apagamento de certas práticas culturais. Em se tratando de uma práxis não escrita, isso seria ainda mais forte, em razão de ela não ter a mesma credibilidade pela perspectiva grafocêntrica. Com isso, essa poesia problematiza as relações entre memória e arquivo, o que exige uma revisão desses termos, a fim de que se delimitem seus alcances.

Diana Taylor compreende arquivo e repertório como duas instâncias simultâneas na cultura latino-americana. Ambos são realizações da memória. Sua diferenciação está na importância conferida ao registro. Entretanto, isso não é compreendido resumidamente como uma diferença entre palavra escrita e falada, mas "[...] entre o arquivo de materiais supostamente duradouros (isto é, textos, documentos, edifícios, ossos) e o repertório, visto como efêmero, de práticas/conhecimentos incorporados (isto é, língua falada, 
dança, esportes, ritual)" (Taylor 2013: 48). Nesse contexto, a escrita não substitui a fala, mas funciona como um auxílio para a transmissão. A concomitância dessas ocorrências invalida a concepção de que uma aniquilaria a existência da outra, assim como a pretensa ideia de hierarquização entre elas, mais comum em culturas europeias. Na realidade, arquivo e repertório trabalham em conjunto.

Enquanto o arquivo tem a pretensão de conservação, o repertório segue o caminho da reiteração. O último demanda a presença de um corpo. Daí a ideia de práticas incorporadas. O corpo presente é suporte e meio de transmissão; a performance, para Taylor, é a reiteração dessas práticas de memória. Não gratuitamente a poesia de Luiz Bacellar convoca a presença do corpo. O sujeito poético dirige-se diretamente ao leitor, demandando sua participação por meio dos sentidos, seja com a visão, seja com a audição. A obra cria um efeito de presentificação duplicado, em que leitor e poeta participam juntos da performance poética. Isso quer dizer que Frauta de barro não estaria entre arquivo e repertório, como se fossem excludentes (de um lado, história literária e arquitetura da cidade; de outro, canto, referências musicais e dança). Embora seja possível analisar a obra de Luiz Bacellar sob esses pontos de vista separadamente, o que existe nela é contiguidade e coexistência desses aspectos.

"Romanceiro suburbano" traz um conjunto de textos em que os arredores da antiga cidade de Manaus aparecem. Não há a grandeza do Teatro Amazonas nem a beleza das igrejas da época, mas os espaços deixados à margem do boom da economia gumífera ou, ainda, considerados secundários naquele momento da história. "Balada da Rua da Conceição" e "Ciranda à roda de um tronco" são exemplos de poemas em que a máscara poética do catador de lixo sai da esfera específica do arquivo para cruzar com o repertório em Frauta de barro. Afeito a um gesto conhecido na cultura brasileira, Luiz Bacellar também estaria em momento de júbilo diante da "riqueza daquilo que se guardaria na experiência coletiva, muitas vezes a contrapelo da aceleração do mundo moderno" (Meira Monteiro 2018: 106). ${ }^{4}$ Essa riqueza cultural é anterior ao poeta. Está no plano de uma agência, de cujas vozes vazam pelo canto épico-lírico como sintomas.

O demolido, o que exala fedor e o que não atende à convenção de beleza são apresentados em "Balada da rua da Conceição". Há no texto de Luiz Bacellar uma dimensão retórica, a qual é inseparável da performance da máscara de catador de lixo. Essa dimensão arquiteta o plano textual, construindo-lhe a plasticidade que dá a ver e a ouvir os estratos de sentido do gênero balada. Explica-se: o poeta solicita ao seu interlocutor que veja o alvo de seu canto: "Vede as fisionomias / desgostosas e alquebradas" e "Vede as ruas tristonhas" (Bacellar 2011: 41). Essas duas ocorrências do verbo ver são somadas a mais três: "Vede os beirais rebentados! / Vede as calhas entulhadas" e "Vede o balcão derrubado" (idem: 42). Em todos os casos, nota-se o tom de súplica, de modo a revelar o esforço de construção desse efeito por meio da incidência do foco sobre as coisas. A quantidade de objetos, entretanto, extrapola os versos mencionados, organizando quase como em lista mais elementos que precisam ser vistos: "e os buracos dos soalhos / e 
os alpendres corroídos / e as cumeeiras caídas" (idem: 42), etc. Assim, pequenos seres e coisas misturam-se a destroços do mundo no decorrer desse longo poema.

No presente caso, três são as imagens temporais dispostas para quem lê. Na medida em que o poeta presentifica objetos, evoca simultaneamente uma totalidade não mais existente. Isso significa que o poema apõe uma imagem virtual, passada, em que o espaço urbano não estava envelhecido, sobre a que se visualiza. Por sua vez, essa segunda imagem - no presente - é o motivo cantado. E sobre ela também se instaura a imagem da destruição, anteriormente anunciada nos dois primeiros versos do texto: "Vão derrubar vinte casas / da rua da Conceição" (idem: 41). Se a destruição se prenuncia como um futuro próximo, é no agora que se instala e reverbera todo dinamismo da balada, como um tempo que se alonga. Desse modo, a enumeração dos termos espaciais, carregada de adjetivações que matizam o estado atual das coisas, traz em seu bojo o desejo de expor - em que pese o sentido de pôr à vista - a perda do referido tempo.

Joana Matos Frias (2009: 31) recobra que não apenas a ação de imitar, mas também que o que era imitado deveria ser posto diante dos olhos, segundo a poética clássica. Para Frias, ao associar essas duas concepções, Aristóteles funda uma identidade entre a mímesis, a imitação, e a ação de pôr à vista, compondo, assim, a particularidade do que o grego chamou discurso eloquente. A base dessa relação de identidade está na palavra grega enargeia:

Na enargeia, é mesmo a «visão como ficção» que passa a estar em causa, e o acto de colocar perante os olhos passa a ser o acto de construir o visível «dando a ilusão da presença». 0 poder desta enargeia está justamente na força da presença fictiva que só existe em estado de palavra. (Frias 2009: 33)

À luz das palavras de Joana Matos Frias, nota-se que a dobra estrutural da sentença encabeçada pela visão é ponto de partida para construir o visível em "Balada da rua da Conceição". A ficcionalização da visão é parte de uma dinâmica de deslocamento. 0 poeta conduz o leitor pelo espaço, guiando-o com as lentes com que observa o mundo. Seguindo uma orientação vertical, estende-se do chão até o alto das casas, para, em seguida, desenvolver seu trajeto. $O$ avançar dos passos determina um entrelaçamento de duas ações, a de ver e a de percorrer, tornando-as indivisíveis. No poema, ver é percorrer. Isso desencadeará duas consequências, referentes ao intercâmbio semântico desses verbos: na primeira, poeta e interlocutor têm seus pontos de observação fundidos; aliado a isso, o deambular feito por eles excederá o espaço físico para percorrer com os olhos também o tempo.

À força fictiva da palavra também concerne a produção de uma forma de pensamento. Na balada, trata-se de um prolongamento da visão que abarcará os três modos de ação: um de caráter narrativo; outro de caráter subjetivo; a eles sucede um gesto dramático, quando da apresentação de falas das personagens. A rigor, essas formas se misturam no interior da 
balada e compõem a totalidade do poema. Assim, quando a cidade é declarada por meio das personagens, ela adquire delas certo animismo. A paisagem, então, transforma-se à medida que também atua - considerados os sentidos teatral e o de exercer uma ação - a partir de si e sobre si.

De acordo com Michel Collot:

O ambiente visual do homem não é uma audição de estímulos pontuais, mas um conjunto estruturado pelo ponto de vista do observador, que põe as coisas em relação umas com as outras, segundo um processo complexo de "ocultação reversível". Isso acontece porque nossa visão jamais nos dá a ver tudo ao mesmo tempo; ela não obtém um panorama, mas um agrupamento de perspectivas parciais, que se modificam e se completam à medida que nosso ponto de vista se desloca. [...] (2013: 21)

As subpartes que compõem o poema abrigam os episódios atravessados pelo poeta. Eles são sinalizados estruturalmente com subtítulos laterais, os quais podem ser lidos como marcas que fornecem uma orientação: apresentado o motivo, tem-se "Os Ratos e o lixo", colocando em primeiro plano seres circunscritos ao espaço; seguido de "As Casas" e "O Sobrado da viúva", expandindo ainda mais o espaço urbano; "Um Certo Dr. Calango", encetando um embrião narrativo, o qual será costurado a outros a partir de "A Conversa das mangueiras". Relacionando o grupo de pequenos episódios ao ambiente visual de que fala Collot, encontram-se neles o conjunto estruturado a ser cerzido na balada. A costura é feita com base no dispositivo de ficcionalização da visão, que altera seu campo de incidência, de sorte que o poeta calibre o escopo do que será visto dentro da cidade. Se o leitor tomasse distância dessas subpartes como em um zoom, poderia enxergar um panorama da cidade. O exercício imaginativo aqui sugerido, todavia, não ocorre no poema. O ver-percorrer expande o campo do que é visto, mas, ao mesmo tempo, impõe um limite reversível, o que conduz à narração progressiva de mais causos daquele lugar e à apresentação de perspectivas de personagens diferentes.

Em seu gesto de fazer presente o que era ausente acessando lembranças, a ficcionalização da visão suplementa os objetos físicos com valores subjetivos. Isso, no entanto, não garante ao sujeito poético a centralidade no discurso, embora pela visão poeta e interlocutor sejam primeiramente afetados. Luiz Bacellar destaca no poema um dos elementos da cidade, elevando as Mangueiras à categoria alegórica ao passo que lhes confere voz e discurso. Quando o sujeito poético informa "Sem querer me pus à escuta / das conversas das mangueiras" (Bacellar 2011: 42), ilustra outra forma de interação entre ele e o espaço. Colocar-se à escuta explicita uma disposição, uma abertura em direção a. A forma de se projetar sobre a cidade pelos ouvidos mostra a própria condição de sua existência. Desse modo, visão e audição são formas de percorrer o mundo. Ao passo que as lembranças de causos e pequenas histórias de personagens que ali viveram começam a ser conhecidas, o sujeito poético excede ainda mais o espaço da interioridade. Aliado 
a isso, reforça-se a ideia de que a paisagem urbana não é meramente pano de fundo, mas faz parte da dinâmica poética. É nesse momento em que a cidade, animada pelas narrativas, avança sobre o poeta. A paisagem urbana, então, será a soma das interações dos sentidos, resultado do jogo entre presenças e ausências, entre interioridade e exterioridade, entre espaço e tempo.

Ocorre a interação entre espaço, linguagem e pensamento no poema. As árvores narram a cidade e tecem considerações sobre o que é narrado. Isso confere às Mangueiras um papel fundamental, pois delas são as vozes que poeta e interlocutor conhecem. Desse modo, a escuta do poeta sedimenta mais um estrato de significação para o horizonte de ocultação reversível.

Ao escrever sobre o canto homérico, Jean-Luc Nancy declara que o aedo ouve e interpreta a voz divina: "ele assim faz o que espera que ela faça a fim de se eclipsar ele mesmo nesse canto". No contexto épico, aquilo que o aedo escutar nele reverberará. Serão nivelados os tons e as harmonizadas dicções; e a voz da musa nele ressoará.

Escutar é ressoar: deixar vibrar em si os sons vindos de alhures, e lhes responder por sua reverberação num corpo tornado cavernoso para esse fim. Essa caverna não é a de Platão: não é fechada e apenas entreaberta sobre um fora que projeta sombras, mas é abertura em si nos dois sentidos que pode tomar essa expressão: ela é a abertura no interior de mim e a abertura mesma, absolutamente. De fato, ela é «eu» enquanto abertura, eu enquanto caixa de ressonância sobre a qual vêm bater, deslizar, roçar os acordes e os acentos das vozes do fora, das vozes divinas. [...] (Nancy 2016: 210)

Advindo do verbo latino resonare ("retinir", "retumbar", "ecoar”), "ressoar" aparece no pensamento de Jean-Luc Nancy como predicado que coloca em evidência uma atividade mútua. Para ilustrar essa duplicidade, a metáfora espacial de um corpo cavernoso joga com os símbolos do corpo e da caverna. Enquanto o corpo sugere o acolhimento e a sensibilidade humanos em relação ao canto, a caverna ilustra o efeito de uma voz subsumida na outra. Não sendo mais possível determinar um ponto de origem ou uma voz primeira, a própria ideia de início perde centralidade para dar lugar à de abertura. A última, nesse caso, torna-se condição de repercussão. Aquele que canta o faz porque se torna aberto: seja caixa de ressonância, seja, ainda, vaso comunicante, a experiência desse eu aberto dá a ele o sentido de sua projeção.

É possível encontrar paralelo entre tal de escuta e a circunstância na qual se coloca o poeta em "Balada da rua da Conceição". Nota-se que nele as vozes das Mangueiras farão eco. Similar à ficcionalização da visão, a atenção conferida ao que está sendo ouvido distingue episódios e tons, variando entre o alegre e o melancólico. Apesar de não se tratar de uma inspiração divina, ${ }^{5}$ aquele que escuta experimenta o sabor do tempo que as Mangueiras apresentam. Não são gratuitas as figuras que orbitam no campo semântico do diálogo, voltado para o passado: o "molecório danado", o sofrimento nos galhos, as 
"saudades" do tempo em que "não tinha cicatrizes" nem "meu tronco enrugado" (Bacellar 2011: 43). Com isso, mobilizam imagens sobrepostas, costurando o fio do tempo em um cruzamento contínuo entre passado e presente.

Ao falar sobre os "bole-boles" (ibidem), ${ }^{6}$ elas se tornam uma referência incontornável do tema da infância. Nesse caso, na voz alegórica ecoam os versos de Casimiro de Abreu. Retomando o que propõe Jean-Luc Nancy, "uma voz são sempre duas vozes pelo menos, sempre polifonada de alguma maneira. Sempre uma voz deve lançar à outra" (Nancy 2016: 212). Tal polifonia7 nos versos da balada invertem o tom do poema romântico "Meus oito anos" e reinscrevem a infância no presente. Trata-se, assim, de um procedimento de retomada e lançamento em novo tom. Recupera-se no poema o contraste entre juventude e velhice, a fim de que ele seja matizado em tom de queixume: "(eu me sinto tão pesada / que tanto é o número deles!)" (Bacellar 2011: 44), informa uma das Mangueiras. A imagem poética dos "bole-boles”, nesse sentido, presentifica a ambientação ausente (a infância), e a brincadeira infantil ressurge com pesar nostálgico.

A paisagem nostálgica faz ressoar em si uma série de tradições culturais que já expuseram literariamente suas teorias da saudade. Quando a balada coloca entre parênteses o efeito pelos sentidos, atualiza a tradição judaico-cristão dos Salmos (136:1-6), na qual o canto é sobrelevado como estratégia de presentificação e reavivamento imagético e sensível. A esse respeito, Marcos Piason Natali interpretou que "o sentimento doloroso [a saudade] é produzido pela impossibilidade de voltar à terra natal” (Natali 2006: 17). E ainda: "rejeita-se fervorosamente o esquecimento do lugar de onde se partiu como forma de acabar com o sofrimento" (ibidem). À guisa das palavras do crítico, nota-se que não se trata, em "Balada da rua da Conceição", de alguém que se afastou do lugar de origem, mas da própria destruição da origem. A ideia de desterramento é apresentada de forma brutal pela transformação que sofre o espaço; consequentemente, o impacto que essa paisagem urbana desencadeia no sujeito poético nele repercute como nostalgia: o canto surge como retomada, como reapropriação do que foi perdido, ou seja, conhecimento incorporado. Preenche-se o canto com desejo, cujo objeto está ausente. Na certeza de que o canto não possui função substitutiva, as narrativas que o preenchem anestesiam os efeitos da expectativa do vazio a ser deixado após a destruição. Isso significa que a projeção da destruição desconcerta o sujeito poético a ponto de nele instalar um estado nostálgico, antevendo as saudades por meio da performance alegórica.

O estado paradoxal inerente ao gesto de reapropriação imaginária é ilustrado pela fala de uma das Mangueiras: "Ai, rua da Conceição / somente retornarás / sob a forma de canção / repleta de nunca mais" (Bacellar 2011: 49). Com isso, vê-se como a performance acomoda uma contradição. Aquilo de que o canto está impregnado são os símbolos que a rua não pode mais abrigar, mas que garantem a ela inegavelmente a sua existência. $A$ rua é, apesar e em razão de sua ausência; ela está a contrapelo do arquivo, de sua materialidade. E enquanto o canto puder hospedá-la, ela ainda será sensível ao poeta. Trata-se, assim, da refundação da origem por outro viés, performático, no qual se prescinde da materialidade urbana. 
No campo dessa sensibilidade, visão e audição são os sentidos postos em destaque. A paisagem urbana é erigida pela performance do catador de lixo, de sorte que impressões e emoções do sujeito poético sejam amalgamadas aos rastros, isto é, ao arquivo do mundo concreto. Por fim, se a paisagem ainda é o que existe no tempo presente, só será acessada perante o mesmo horizonte que se dá a ver e a ouvir nesse tempo.

Além da recuperação de um lugar comum na poesia brasileira, a mangueira é a destinatária do canto. Em "Ciranda à roda de um tronco", o poeta não apenas canta os componentes do espaço urbano, mas igualmente canta para ele. Trata-se de um modo de fazê-lo adquirir importância singular. Se "Balada da rua da Conceição" revela dimensões arquivais e performáticas, "Ciranda à roda de um tronco" demonstra, por seu turno, outro repertório em Frauta de barro. Além de reportar-se à literatura brasileira, Luiz Bacellar manuseia um substrato que não obedece ao literário e comunica algo guardado na memória coletiva. Em certa medida, esse gesto novamente acena para autores como Mário de Andrade e Guimarães Rosa, os quais anteriormente escolheram materiais culturais brasileiros de regiões diversificadas.

Duas são as figuras principais do poema: o cantador ${ }^{8}$ e a ciranda ${ }^{9}$ Frauta de barro dá um sinal da presença nordestina no Amazonas, assimilando-a e reconfigurando-a poeticamente em máscara de um catador-cantandor. Ele migra de um poema para outro como se fechasse uma cena e abrisse um novo momento ou nova estação. O procedimento de ocultação reversível de "Balada da rua da Conceição" estende-se, assim, para as demais partes do livro.

A ciranda é uma manifestação cultural que não acontece em teatros, mas em espaços construídos para festivais sazonais. Nesse sentido, ela é marcada pelo provisório e não se enquadra às condições do arquivo enquanto instituição tradicional nem à recolha dos restos com os quais poderia se escrever a História; consequentemente, não deveria ser interpretada de acordo com os mesmos procedimentos hermenêuticos. Como nas músicas cantadas nos festivais, "Ciranda à roda de um troco" traz um elemento do mundo cotidiano, a mangueira, e sobre ele versa um pequeno episódio sem densidade narrativa. Matizando o contexto citadino, a sonoridade mescla a fala cotidiana com o canto. Parece não haver interesse em diferenciar o poético e o popular, tornando o limite entre eles impreciso.

\footnotetext{
Mangueira de minha rua

Do velho tronco enrugado

Que serves de alcoviteira

Ao casal de namorados.

O vento mexericando

Com tuas folhas assanhadas

Te arrepia as verdes franjas
} 


\begin{abstract}
Em murmúrios assustados.
As formas dos papagaios

Te pendem das galharias

Como brancos esqueletos

De duendes enforcados.

Te escorre o luar das folhas

Com seu brilho niquelado

Como um colar de rainha

Sobre um dossel desfiado.

(Bacellar 2011: 51)
\end{abstract}

O texto tem em seu núcleo a ideia de ritmo. Jogando com simetrias e assimetrias, seu plano sonoro sugestiona um movimento, enquanto suas imagens exprimem outro. Desse modo, o avançar pelas estrofes garante à mangueira a adição de significados que apontam para vetores diferentes. Em todos eles, há um corpo que mantém a organicidade do poema.

Formado por quadras, o poema reproduz um esquema métrico em redondilha maior, remetendo novamente à cultura popular. O esquema de rimas, entretanto, contraria essa regularidade. Apesar da simetria métrica, a força que recai sobre a rima $B$ (sensível nos versos 2, 4, 8, 12, 14, 16) transcorre todo o texto como um som arranhado. O poema não está arraigado à repetição regular nas rimas pares. Pesa sobre ele a interrupção produtora de ruído, marcando um contraste com as demais. Assim, os dois traços sonoros criam o efeito de toque desafinado.

Em estudo sobre o ritmo, Olga Guerizoli Kempinska desassocia-o da tradição de leitura canonizada, que o vincula à regularidade e à repetição. A autora compreende-o como "produto da cultura", o que suscita uma reorientação de seu sentido convencional.

[...] Projetado sobre a natureza e tido como responsável pela representação da correspondência entre o corpo humano e o universo, o ritmo é, na realidade, um produto da cultura. Descrito através de metáforas que, tal como a do coração ou a da respiração, remetem ao movimento dos órgãos, o ritmo não pode, no entanto, limitar-se à fisiologia do corpo biológico, sendo também uma forma de inscrição do indivíduo no domínio da vida coletiva e da história. Dificilmente situável nos extremos das oposições antropológicas e sociológicas - nós o produzimos e, igualmente, somos seus produtos - o ritmo parece ter uma dupla vocação, estimulando tanto a participação quanto a resistência. (Kempinska 2014: 113)

Ritmo é projeção e interpretação, logo, é resultado de um gesto hermenêutico. Afastado da ideia de cadenciamento predeterminado, o ritmo tem seu fundamento de acordo 
com a cultura. Não é algo anterior a ela, mas produzido e atualizado pelas dinâmicas da cultura que o toma. Traduzindo essa ideia para o poema de Luiz Bacellar, a produção de um descompasso com a irregularidade das rimas afeta o plano das imagens e sugere uma performance rítmica da vida da comunidade. Essa ação convoca para o texto a presença de um corpo. Não um corpo isolado ou apartado da agência. Mas um corpo em ato, situado na ciranda que o título informa. Ele está inserido em uma coletividade, em que um número indefinido de corpos individuais dança ao redor de um tronco. O leitor está diante não apenas da mangueira à qual o canto é dirigido, mas de toda a performance que o poeta apresenta. Da mesma forma, torna-se participante da dança em que o poeta está.

A performance coletiva baseia-se em dois elementos principais: a ciranda e o tronco. A dança popular concentra em si uma ideia de dinamismo; ultrapassa o sentido do corpo individual e biológico para alcançar o domínio da vida coletiva de que fala Kempinska. A vida cotidiana implica o provisório, enquanto a mangueira remete ao que perdura. Embora destacada, a árvore não está apartada do urbano, mas imersa nele. Ela funciona como imbricamento dessas dimensões, indicando encontro e diferença entre elementos. Quando o poeta a toma como alegoria "de minha rua", cruza os corpos individuais e engendra um corpo coletivo. O cantor e todos os que circundaram em algum momento a árvore têm sua memória atrelada à memória da cidade, de modo que haja confluência entre os diversos tempos. Paralelamente, há uma diferença entre o ritmo da vida humana e o da árvore. A adjetivação do tronco sinaliza a contiguidade entre essa árvore e o espaço de "Balada da rua Conceição". A árvore atravessa gerações, opondo-se às vidas humanas. Ela é o abrigo provisório para o amor na primeira estrofe, mas temporalmente demonstra ser sua duradoura antípoda. Os "papagaios" 10 pendurados sobre os galhos correspondem aos "brancos esqueletos" de "duendes enforcados". Essas comparações exprimem a transformação da paisagem nas estrofes finais. Dessa forma, a ciranda de Luiz Bacellar joga com a ideia de infância, ao passo que não abole a de rito totêmico, no momento em que suas imagens finais concedem ao espaço uma atmosfera soturna, fazendo da mangueira também um indício da morte. A dança anuncia, então, os ritmos da vida - dinâmicos, policrônicos, múltiplos e, na maioria das vezes, desalinhados, em função das figuras que compartilham histórias em espaço e vida comuns.

A respeito de Luiz Bacellar, Miriam de Carvalho escreve:

Em meio a demolições, ao lixo, aos ratos e urubus, em meio ao lirismo que resta para referendar sua cidade e poetizar os objetos, com afinado instrumento musical o poeta vai soprando a cor cinza da poeira que atinge as coisas do dia a dia. Épica e lírica, barro e melodia, essa frauta vem rastreando o pensar poético: um pensamento dinâmico que vai ao fundo das coisas e da linguagem, refletindo-se no fazer poético. (Carvalho 2011: 140) 
Nos dois poemas elencados, o catador-cantador altera a configuração do mundo composto pelas coisas, intercalando entre alto e baixo e invertendo valores. Ele perfaz o rastreamento e promove a transformação do espaço, à medida que capta elementos e conduz o pensamento ao que não seria sequer foco de observação. Há episódios em que a voz épica se eleva; em outros, como em "Ciranda à roda de um troco", acentua-se o lirismo. O pensamento dinâmico do poeta modaliza o verso às circunstâncias, de modo que o fazer poético melhor traduza suas intenções. Nesse sentido, a coroação da árvore encerra os passos da performance dos ritmos da vida. O poeta investe sobre o corpo da mangueira outros corpos de sentido, de modo que ela deixe de ser um item banal do mundo para ser elevada à realeza. Isso sugere o afastamento progressivo do real, ao passo que performatiza a memória incorporada da ciranda. Assim, não há um desfecho narrativo, mas o término do poema intencionalmente em estado de contemplação da mangueira e da infância que ela traz à tona.

Da sonoridade às imagens, o poema suscita a reflexão sobre o descompasso entre os tempos. A interrupção da rima constrói um pensamento sobre a impossibilidade da repetição exata. Sua ciranda é feita com outra ideia de ritmo, em que temporalidades coexistem e não produzem harmonia. Como alegoria de tempos plurais, a mangueira então sinaliza ritmos variados. O poeta marca a diferença; não a identidade.

Desse modo, há a seguinte indagação: por que motivo Luiz Bacellar "repetiria" o mesmo correlato objetivo - a mangueira - em dois poemas subsequentes no livro? Não se deseja incorrer em um questionamento de ordem biográfica. Na realidade, a resposta é dada pelo próprio texto. Encontra-se no par recomeço-variação do poema de abertura de Frauta de barro, agora subsumido em "Romanceiro suburbano". A estrutura de pensamento do poema inicial atravessa o livro, tocando figura literária e brincadeiras infantis. Ao falar dos "bole-boles", em "Balada da rua da Conceição", e dos "papagaios", em "Ciranda à roda de um tronco", Luiz Bacellar relê a mangueira como o topos literário da infância. Em sua interpretação, a infância mitificada da poesia romântica sofre uma rasura, pois o poeta inscreve sobre ela brinquedos reprocessados como símbolos da morte. Eles anunciam a impossibilidade de retorno que se impõe sobre o presente, o que impele o poeta a uma única forma de acesso ao que se perdeu - o cultivo das lembranças. A recolha a partir do lixo resvala na resistência ao apagamento das vozes daquele mundo. A reiteração do canto, assim, ultrapassa a denúncia e mantém-nas vivas com a memória que o canto abriga.

A infância e o repertório contêm uma semelhança: ambos são irrepetíveis. E é apenas pela reiteração de certas práticas que a memória do tempo e do lugar são transmitidas uma vez mais. Por esse caminho, retomam-se palavras de Diana Taylor, para quem

O repertório [...] encena a memória incorporada - performance, gestos, oralidade, movimento, dança, canto -, em suma, todos aqueles atos geralmente vistos como conhecimento efêmero, não reproduzível. O repertório, etimologicamente "uma tesouraria, um inventário", 
também permite a agência individual, referindo-se também a "aquele que encontra, descobridor". O repertório requer presença - pessoas participam da produção e reprodução do conhecimento ao "estar lá", sendo parte da transmissão. Em oposição aos objetos no arquivo, supostamente estáveis, as ações do repertório não permanecem as mesmas. O repertório ao mesmo tempo guarda e transforma as coreografias de sentido. [...] (Taylor 2013: 49)

Além da dimensão provisória, há no repertório a irreprodutibilidade. Capturá-lo por qualquer formato construiria uma forma arquival a partir dele. "Romanceiro suburbano" problematiza essa questão ao se fazer uma coleção de causos e histórias da cidade. Por esse caminho estarão "Receita de Tacacá", acenando para a culinária; "Balada da rua das 13 casas", em que a destruição das casas ganha importância novamente; ou "Beco do 'Pau não Cessa'”, em que a história do beco será contada. O poeta andarilho faz um inventário do mundo conhecido, recolhendo o que é digno de transmissão. A natureza do que foi escolhido tem constantemente sua configuração alterada. A música investe sobre as coisas uma aura singular. É por ela que são transformadas as coreografias de sentido, isto é, desfaz-se a significação referencial das coisas para que elas assumam no canto do poeta um sentido próprio. Quando inventariadas, tornam-se parte dessa coleção afetiva. O gesto que essa poesia propõe se faz a contrapelo da prossecução do tempo. Isso não anula a consciência do limite da própria atitude diante do repertório. Se a singularidade desse reside na efemeridade, também subsiste nela a mudança que levará ao desaparecimento do próprio repertório. Desse modo, a reiteração se mostra um fundamento importante. A humanidade reitera comportamentos e práticas porque compreende que uma memória deve permanecer. Luiz Bacellar parece ter clareza desse fato. Por esse motivo manipula as duas dimensões: arquivo e repertório se cruzam entre epígrafes, nomes de ruas, lugares comuns da tradição literária e cultura não escrita. O poeta não só caminha pela cidade fantasmal de suas lembranças, mas apresenta os sabores mistos da infância. Assim, desfaz interpretações opositoras dessas noções e demonstra suas coexistências no mundo. 


\section{NOTAS}

* Fadul Moura é doutorando do Programa de Pós-graduação em Teoria e História Literária da Universidade Estadual de Campinas, com bolsa de estudos concedida pela Fundação de Amparo à Pesquisa do Estado de São Paulo (Processo n²018/07075-0, Bolsa de Doutorado no País), e está vinculado ao Exodus - Núcleo de Estudos sobre Produções Culturais Extemporâneas e Excêntricas na Era dos Extremos: Brasil, América Latina e Outras Regiões.

${ }^{1}$ Trata-se do período entre a Revolução Industrial e o desenvolvimento da educação no país. Parte das teses de Antoine Compagnon foram apresentadas no curso Littérature française moderne et contemporaine: histoire, critique, théorie, realizado no Collège de France; e na palestra Grandeur et décadence du chiffonnier de Paris, realizada no Musée d'Orsay (2017).

${ }^{2}$ Selecionando pintores do século XIX, Antoine Compagnon informa que o chiffonnier é representado da mesma maneira, com três ferramentas: 1 . o cesto nas costas (hotte sur le dos); 2 . uma espécie apanhador de lixo, cuja ponta tem formato de gancho (crochet); 3. a lanterna, a qual aparece em suas representações de ambientação noturna.. O chiffonnier pisava no papel, esmagando-o; essa era uma etapa de trabalho da produção de papel, para que mais tarde fosse utilizado na produção de livros, por exemplo, o que contribuiu para a associação de seu trabalho à literatura, em comparação frequente com a figura do escritor.

${ }^{3} \mathrm{O}$ último parágrafo indica: “Je n’ai pas quitté mon Chiffonnier compilateur, sans lui laisser un bon à-compte sur les frais du Prospectus". Cf. Jouy, Etienne. Les hermites en liberté. Disponível em: <https://gallica.bnf. fr/ark:/12148/bpt6k63786116/f125.item.r=les\%20hermites\%20en\%20libert\%C3\%A9> (último acesso em 23/07/2020).

${ }^{4}$ Pedro Meira Monteiro (2018: 106) continua: “O ato de resistência do estudioso que rejeita a massificação da indústria cultural e mergulha nos grotões em busca do tesouro perdido da cultura do povo possibilitaria, em suma, flagrar e registrar a multiplicidade das manifestações coletivas, no momento em que elas estariam enfeixando-se num poderoso vetor". As palavras do crítico recaem sobre a obra de Mário de Andrade, primeiro autor brasileiro a dedicar-se criticamente sobre essa ideia de cultura brasileira. Encontra-se uma atitude similar à do paulista no momento em que Bacellar também apresenta uma vox populi em seu épico-lírico. A peculiaridade do amazonense, porém, é que nele não se verifica o apaziguamento de tensões.

${ }^{5}$ Nancy aponta no início de sua argumentação que o destinatário de quem canta foram dados vários nomes pela tradição: “[...] Musa, Furor poético, Gênio (com ou sem maiúscula), inspiração, missão ou vocação, necessidade da alma ou da mente, graça do céu, injunção sagrada, dever de memória ou de esquecimento, autoengrendramento do texto" (2016: 209). Ele recupera essas nomenclaturas para retornar à mais antiga, extraída da llíada, e desenvolver sua análise sobre o canto homérico. Na balada de Luiz Bacellar, é apresentada a memória da cidade, de tal modo que no poeta ressoam as memórias do lugar. Cantar a cidade, nesse sentido, torna-se um dever de memória, que manterá viva a paisagem imaginária, apesar da transformação do espaço.

${ }^{6}$ Trata-se de pedras que as crianças utilizavam, amarradas em linhas, para roubar frutas. Tal prática acontecia em um tempo em que as brincadeiras de rua eram mais comuns, sugere o poema. 
${ }^{7}$ Em seu pensamento, Nancy ainda explicita que uma voz em si não é considerada uma voz, pois nessa condição é alheia a qualquer endereçamento, fazendo-se, assim, "mutismo enclausurado em seu mutismo" (2016: 212-213). Polifonada, ela se lança em direção à escuta; engaja-se em outra voz. Assim, para o filósofo, a escrita denota essa forma de engajamento da voz. Isso faz com que Homero não cante apenas para si, mas para outros de seu próprio tempo e para além dele.

${ }^{8}$ Segundo Luís Câmara Cascudo, o cantador é um cantor popular comum no Nordeste do Brasil: “[...] representante legítimo de todos os bardos, menestréis, glee-men, trouvères [...], dizendo pelo canto, improvisado ou memorizado, a história de homens famosos da região, os acontecimentos maiores, as aventuras de caçadas e de derrubadas de touros, enfrentando os adversários nos desafios que duram horas ou noites inteiras, numa exibição assombrosa de imaginação, brilho e singularidade na cultura tradicional. [...]" (Câmara Cascudo 2005: 236-237).

${ }_{9}^{9}$ Sobre essa dança popular oriunda de Portugal e difundida pelo Norte e pelo Nordeste do Brasil, Mário de Andrade escreve uma crônica, intitulada "A ciranda", no momento da viagem feita pelo autor em 1927 por essas regiões brasileiras. A ciranda, escreve Mário de Andrade, é composta por pares; “[...] uma orquestrinha de violões e cavaquinhos acompanha as cantorias, ritmadas com força pela assistência batendo palmas. Um ou dois cantores solistas, fazendo mais ou menos o papel do Histórico dos oratórios clássicos, puxam os cantos, enquanto outros figurantes solistas representam dentro da roda o que o Histórico vai contando [...]" (Andrade 2015: 414).

${ }^{10}$ No Brasil, “papagaio" é sinônimo de "pipa”. Cada nome funciona como variante regional que indica o mesmo brinquedo infantil, feito de papel ou tecido em formato geralmente quadrangular, com estrutura composta por talhas de galhos leves e linhas. Outros nomes podem ser usados, a depender da região do país.

\section{BIBLIOGRAFIA}

Andrade, Mário de (2015), O turista aprendiz, Brasília, Iphan.

Bacellar, Luiz (2011), Frauta de barro, Manaus, Valer.

Câmara Cascudo, Luís da (2005), Dicionário do folclore brasileiro, Ediouro Publicações, São Paulo.

Carvalho, Mirian de (2011), "Crônica de leitura de imagens ritmadas em barro e sopro", in Frauta de barro, Manaus, Editora Valer: 123-141.

Collot, Michel (2013), Poética e filosofia da paisagem, coordenação de Tradução Ida Alves, Rio de Janeiro, Editora Oficina Raquel. 
Compagnon, Antoine (2016), "Les chiffonniers littéraires: Baudelaire et les autres (20152016)", Disponível em: <https://www.college-de-france.fr/site/antoine-compagnon/ course-2015-2016.htm>. (último acesso: 04/07/2020).

-- (2018), "Grandeur et décadence du chiffonnier de Paris", Disponível em: <https://www. youtube.com/watch?v=Jg2ypqQVMIE\&feature=youtu.be> (último acesso: 04/07/2020).

Lapa, Rodrigues (1970), Lições de literatura portuguesa: época medieval, Coimbra, Coimbra Editora.

Frias, Joana Matos (2009), “A retórica da visão na poética clássica”, in As artes de Prometeu: estudos em homenagem a Ana Paula Quintela, Porto, Editora da Univ. do Porto: 25-41.

Kempinska, Olga Guerizoli (2014), "O ritmo e o gênero", Remate de Males, v. 34, n. 1, Disponível em: <https://periodicos.sbu.unicamp.br/ojs/index.php/remate/article/ view/8635835> (último acesso em: 09/07/2021).

Marques, Reinaldo Martiniano (2015), Arquivos literários: teorias, histórias, desafios, Belo Horizonte, Editora UFMG.

Meira Monteiro, Pedro (2018), "A transparência do canto e o obstáculo do mundo: o tempo no modernismo de Mário de Andrade", Luso-Brazilian Review, v. 55, n. 2, Disponível em: <https://www.academia.edu/38170475/A_transpar\%C3\%AAncia_do_canto_e_o_ obst\%C3\%A1culo_do_mundo_o_tempo_no_modernismo_de_M\%C3\%A1rio_de_ Andrade> (último acesso em 10/05/2021).

Taylor, Diana (2013), O arquivo e o repertório: performance e memória cultural nas Américas, tradução de Eliana Lourenço de Lima Reis, Belo Horizonte, Editora UFMG.

Moreira, Luana Aguiar/Leão, Allison (2020), "Processo de Criação e Gênese Imaterial da Poesia de Luiz Bacellar", Manuscrítica: Revista de Crítica Genética, $n^{\circ}$ 42, Disponível em: < https://www.revistas.usp.br/manuscritica/article/view/178322> (último acesso em 24/06/21).

Nancy, Jean-Luc (2016), Demanda: Literatura e Filosofia, tradução João Camillo Penna, Eclair Antonio Almeida Filho, Dirlenvalder do Nascimento Loyolla, Florianópolis, Ed. UFSC; Chapecó, Argos.

Natali, Marcos Piason (2006), A política da nostalgia: um estudo das formas do passado, São Paulo, Nankin. 